\title{
Corrigendum
}

\section{Hsa-miR-623 suppresses tumor progression in human lung adenocarcinoma}

\author{
Shuang Wei, Zun-yi Zhang, Sheng-ling Fu, Jun-gang Xie, Xian-sheng Liu, Yong-jian Xu, Jian-ping Zhao and Wei-ning Xiong
}

Cell Death and Disease (2017) 8, e2829; doi:10.1038/cddis.2017.254; published online 25 May 2017

Correction to: Cell Death and Disease (2016) 7, e2388; doi:10.1038/cddis.2016.260; published online 29 September 2016

Since the publication of this article in Cell Death and Disease in 2016, the authors noted an error contained in Figure 7a, in that, the western blot image for MMP9 was incorrect. The correct blot image is now included in the figure given here.

The corrected article appears online together with this corrigendum.

The authors would like to apologize for any inconvenience caused. (c) (i) Cell Death and Disease is an open-access journal published by Nature Publishing Group. This work is licensed under a Creative Commons Attribution 4.0 International License. The images or other third party material in this article are included in the article's Creative Commons license, unless indicated otherwise in the credit line; if the material is not included under the Creative Commons license, users will need to obtain permission from the license holder to reproduce the material. To view a copy of this license, visit http://creativecommons.org/licenses/by/4.0/

(C) The Author(s) 2017

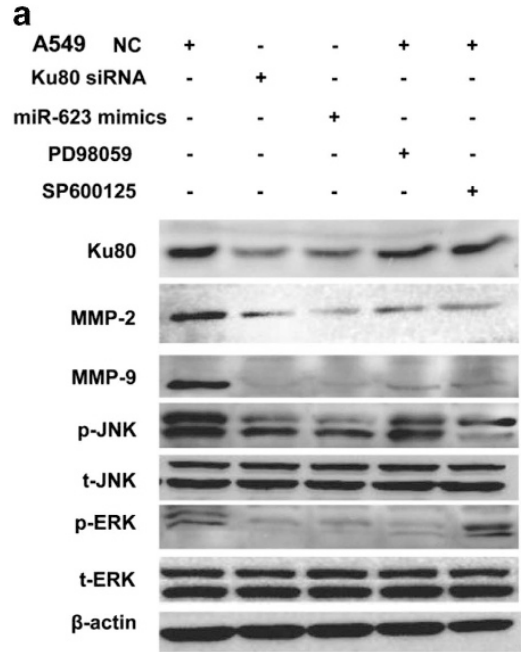

b

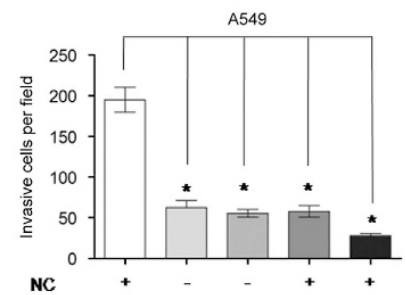

C

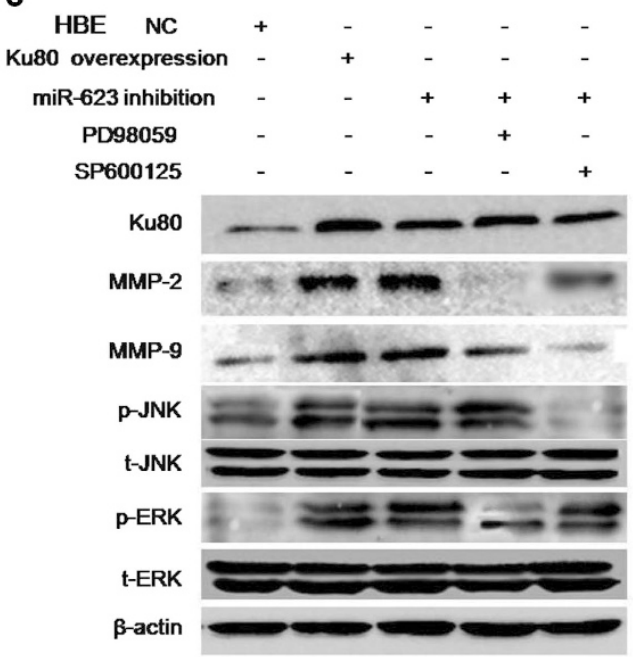

d

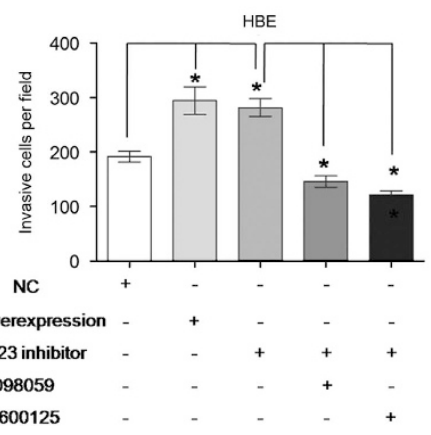

